\title{
Technology development for the production of soy protein supplements in meat products
}

\author{
Abdunabi Fathullaev ${ }^{1, *}$, Islomjon Abdumalikov ${ }^{1}$, Sitora Vakilova ${ }^{1}$, Mirakhmad Ruzmatov ${ }^{1}$, \\ and Temurbek Temurov ${ }^{1}$ \\ ${ }^{1}$ Tashkent State Agrarian University, University str., 2, Tashkent province, Uzbekistan, 100140
}

\begin{abstract}
Functional properties of traditional soy concentrate and its analogue were investigated in this paper. Besides that, a comparative analysis of functional-technological, structural mechanical properties and quality traits of thermally treated ground meat systems was carried out and deeply examined.
\end{abstract}

\section{Introduction}

At present, there is a lack of food rich in easily digestible proteins in the diet of the population. One of the ways to solve this problem is to replace animal proteins with vegetable ones, which are both cheaper and healthier [1]. Soy is the only crop that contains high quality protein. Soy protein is well balanced in essential amino acids other than methionine and cysteine. In terms of the protein complex and the content of essential amino acids (lysine and tryptophan), soy protein is closer to proteins of animal origin, therefore, animal and human organisms spend minimal efforts to convert soy protein into proteins of their body $[2,3]$.

Meat products contain $15-20 \%$ protein. Among vegetable legumes (beans, peas), vegetable soybeans have no equal in terms of protein content (44-45\%) and oil (20-22\%) in the phase of green beans [4]. This is a very highly nutritious crop and the inclusion of vegetable soybeans in the diet allows to enrich food with essential proteins and other nutrients for the body $[4,5]$.

Numerous studies confirm that soybean seeds contain antioxidants. Its use in food helps to increase the body's immunity and reduce allergies. Unlike meat, soy is free of cholesterol and saturated fatty acids, which lead to heart disease, cancer and osteoporosis. It has been noticed that soy effectively lowers blood cholesterol levels, optimizes the glucose content in it in diabetes, helps to strengthen bones, prevents the development of heart and blood vessel diseases, and reduces the risk of kidney and liver stones. Soy contains a very rare fatty acid, omega-3, which is essential for brain development in newborns, reducing the risk of heart disease and cancer. It contains many anticarcinogenic substances that prevent and stop the development of cancerous tumors [5-7].

The use of soybeans is carried out in several directions, among which the following lines are highlighted:

\footnotetext{
* Corresponding author: fabdunabi@mail.ru
} 
Soy protein is produced from raw beans using a multi-stage processing technology that removes indigestible components and concentrates the protein. The type of final product depends on the type of processing. Protein can take the form of a concentrate, isolate, or flour. In addition to protein, soy products contain no less valuable components - fiber, isoflavones, and saponins [8].

The ideal raw material for the production of concentrates is full fat extruded soybeans. The content of vitamins and essential amino acids in concentrates is much higher than in other types of proteins of animal and plant origin $[2,8]$.

On the basis of protein, highly effective protein-vitamin and mineral complexes are obtained - soy protein concentrates, consisting of soy proteins, vitamins, minerals and enzymes $[1,9]$.

The introduction of soy protein concentrates, consisting mainly of salt-soluble proteins, into meat systems ensures the formation of meat emulsions, stabilizes their properties, increases the level of fat absorption, water-binding capacity and stickiness of minced meat. As a result, the output of finished products increases, the likelihood of the formation of broth-fatty edema is excluded, and the product is solid and juicy [9].

In terms of its functional and technological properties, soy protein concentrate acts similarly to the structure-forming muscle proteins of lean meat. However, unlike multicomponent meat and dairy proteins, soy protein concentrate is homogeneous and this makes it easy to predict the nature of technological changes in meat emulsions when working with it and control it [2,5].

Due to the stability of the composition and functional and technological properties, soy protein concentrate provides a significant improvement in the quality of meat emulsions prepared from low grade raw materials with a wide range in the content of muscle, adipose and connective tissue, as well as from ice cream and thawed meat $[4,5]$.

Soy protein concentrate can be used both for the production of a wide range of traditional meat products and for the production of new types of products [10]. At the same time, the optimal level of its introduction into the formulations of various types of meat products is: for boiled sausages, frankfurters, small sausages - $2-4 \%$, for products such as ham in a shell $-2-4 \%$, for salty pork products (when added in brines) - $12 \%$, for pates (molded, wrapped and canned) - 3-6\%, for chopped semi-finished products - up to $7 \%$, for dry fermented sausages $-2-3 \%$.

\section{Materials and methods}

The value of the output of finished products is one of the criteria that determine the economic feasibility of the production of cooked sausages. At the same time, it is closely related to the functional properties of the proteins of the minced meat system, which determine the juiciness of the finished product.

One of these properties is the ability of minced meat to retain bound moisture during heat treatment. In our opinion, water-retention capacity (WRC) and structural-mechanical characteristics are the key functional properties for assessing the quality of cooked sausages.

The water-holding capacity data indicate that the moisture-holding capacity of heattreated minced meat does not differ significantly. The WRC of the control sample, the main recipe component of which is grade 1 beef, is slightly lower than in the samples containing $25 \%$ suspension of modified soy concentrate and $25 \%$ suspension of soy concentrate. These data confirm the previously obtained functional properties of the modified soy concentrate and soy concentrate. 
The use of $25 \%$ modified soy concentrate in the production of cooked sausages instead of an equivalent amount of raw meat allows to create a stable emulsion that retains weakly bound moisture when heated [11].

The structural and mechanical properties of sausages were determined using the INSTRON laboratory installation of the city sanitary epidemiological station [11].

\section{Results and discussion}

Characterizing soy protein concentrates as functional ingredients, the following indicators were chosen as the main criteria for assessing their structural similarity with meat systems: solubility, water retention capacity, critical concentration of gelation, emulsion stability, and fat retention capacity of dry preparations.

Solubility is used as a primary indicator of the quality of the dietary protein. For example, an increase in protein solubility helps to increase the stability of the emulsions stabilized by it. The most important functional protein families include the critical concentration of its gelation, at which a spatial network is formed in the entire volume of the system.

Amino acid composition data indicate that all samples, regardless of the content of other modified proteins, contained a full range of essential amino acids. Minor differences in indicators were due to the research methodology and did not go beyond the permissible deviations. The objective of this study was to investigate protein processing behavior and determine its key functional properties for combined meat products containing other plantderived proteins.

Table 1 shows the amino acid composition of the protein of defatted soy flour and its with other analogues. Control samples 1 and 3 are traditional soy protein preparations, and samples 2 and 4 are their modified counterparts.

Table 1. Protein amino acid composition of defatted soy flour

\begin{tabular}{|c|c|c|c|c|}
\hline \multirow{2}{*}{ Amino acid } & \multicolumn{4}{|c|}{ Amino acid content in samples, $\mathrm{g} / \mathbf{1 0 0} \mathrm{g}$ of protein } \\
\hline & 1 & $\begin{array}{l}2 \text { (modified analogue } \\
\text { of sample 1) }\end{array}$ & 3 & $\begin{array}{c}4 \text { (modified analogue } \\
\text { of sample } 3 \text { ) }\end{array}$ \\
\hline Alanine & 4.3 & 4.5 & 4.2 & 4.3 \\
\hline Arginine & 7.6 & 7.6 & 6.4 & 6.6 \\
\hline Aspartic acid & 11.6 & 12.0 & 12.2 & 11.9 \\
\hline Glutamic acid & 19.1 & 19.4 & 20.0 & 19.6 \\
\hline Cystine & 1.5 & 1.4 & 1.5 & 1.5 \\
\hline Glycine & 4.2 & 4.1 & 3.7 & 3.8 \\
\hline Histidine & 2.6 & 2.6 & 2.8 & 2.7 \\
\hline Isoleucine & 4.9 & 4.8 & 4.6 & 4.8 \\
\hline Leucine & 7.8 & 7.9 & 8.5 & 8.3 \\
\hline Lysine & 6.4 & 6.5 & 6.2 & 6.2 \\
\hline Methionine & 1.4 & 1.4 & 1.4 & 1.5 \\
\hline Phenylalanine & 5.2 & 5.1 & 5.1 & 5.3 \\
\hline Proline & 5.1 & 5.3 & 5.0 & 5.1 \\
\hline Serine & 5.2 & 4.9 & 4.5 & 4.6 \\
\hline Threonine & 3.6 & 3.5 & 3.7 & 3.7 \\
\hline Tryptophane & 1.4 & 1.3 & 1.4 & 1.5 \\
\hline Tyrosine & 3.8 & 3.9 & 4.0 & 4.2 \\
\hline Valine & 4.7 & 4.9 & 5.2 & 5.2 \\
\hline
\end{tabular}


Amino acid composition data indicate that all samples, regardless of the content of other modified proteins, contained a full range of essential amino acids. Minor differences in indicators were due to the research methodology and did not go beyond the permissible deviations. The objective of this study was to investigate protein processing behavior and determine its key functional properties for combined meat products containing other plantderived proteins.

The studies were carried out in a wide $\mathrm{pH}$ range depending on the salt concentration and temperature conditions. The fat-holding capacity of the preparation was $1.0 \mathrm{~g}$ oil for both samples. The values of the indicators of solubility, water retention capacity and critical concentration of protein gelation of the modified soybean concentrate are comparable with the same indicators of the protein of soybean concentrate produced from local soybean seeds.

When determining emulsion stability, no stratification of emulsions stabilized by samples of soy concentrates occurred. The absence of significant differences in the functional properties of the protein of modified soy concentrates and exogenous analogs confirms their identity. The functional properties of soy concentrate (control) and its modified analogue are given in Table 2.

Table 2. Indicators of the functional properties of soy concentrate

\begin{tabular}{|c|c|c|c|c|}
\hline \multirow{3}{*}{ Index } & \multicolumn{4}{|c|}{$\begin{array}{l}\text { Functional properties of modified soy concentrate and soy } \\
\text { concentrate }\end{array}$} \\
\hline & \multicolumn{2}{|c|}{ In water } & \multicolumn{2}{|c|}{$\begin{array}{l}\text { In } 2.5 \% \text { sodium chloride } \\
\text { solution }\end{array}$} \\
\hline & \multicolumn{2}{|c|}{$\begin{array}{l}\text { Modified soy concentrate } \\
\text { control }\end{array}$} & \multicolumn{2}{|c|}{$\begin{array}{l}\text { Modified soy concentrate } \\
\text { control }\end{array}$} \\
\hline $\mathrm{pH}$ of $5 \%$ suspension & 6.9 & 6.7 & 6.3 & 6.2 \\
\hline \multicolumn{5}{|l|}{ Solubility at $\mathrm{t}^{0}, \%$ : } \\
\hline $20^{\circ} \mathrm{C}$ & 51 & 57 & 48 & 46 \\
\hline $72^{\circ} \mathrm{C}$ & 57 & 74 & 51 & 61 \\
\hline $\begin{array}{c}\text { Water retention } \\
\text { capacity of the } \\
\text { preparation, g water/g }\end{array}$ & 5.0 & 5.5 & 4.5 & 5.0 \\
\hline \multicolumn{5}{|l|}{ Emulsion stability at $\mathrm{t}^{0}$ : } \\
\hline $20^{\circ} \mathrm{C}$ & \multicolumn{4}{|c|}{ Resilient } \\
\hline $72^{\circ} \mathrm{C}$ & \multicolumn{4}{|c|}{$»$} \\
\hline $\begin{array}{l}\text { Critical concentration } \\
\text { of gelation at } t^{0}:\end{array}$ & \multicolumn{4}{|c|}{$\gg$} \\
\hline $4^{0} \mathrm{C}$ & 18.2 & 16.7 & 16.7 & 18.2 \\
\hline $20^{\circ} \mathrm{C}$ & 18.2 & 16.7 & 16.7 & 19.0 \\
\hline
\end{tabular}

The fat-holding capacity of the preparation was $1.0 \mathrm{~g}$ oil $/ \mathrm{g}$ preparation for both samples. The values of the indicators of solubility, water retention capacity and critical concentration of protein gelation of the modified soybean concentrate are comparable with the same indicators of the protein of soybean concentrate produced from local soybean seeds.

When determining emulsion stability, no stratification of emulsions stabilized by samples of soy concentrates occurred. The absence of significant differences in the functional properties of the protein of modified soy concentrates and exogenous analogs confirms their identity.

Studies have shown that the most effective interaction of plant and meat proteins occurs when $25 \%$ of modified soy concentrate is replaced. This sample was selected for further 
research. At the second stage, the objects of study were boiled sausage "Extra" 1st grade, in the formulation of which there is no vegetable protein (sample 1 - control), the content of a $25 \%$ suspension of modified soy concentrate (sample 2).

Analysis of the data presented allows us to characterize samples containing a suspension of modified soy concentrate and soy concentrate as having a high yield and a low value of the mass loss index during heat treatment. Indicators of weight loss of the studied mincemeat vary from $13, \%$ (without vegetable protein preparation) to $11.2 \%$ and $11.3 \%$, containing suspensions of modified soy concentrate and soy concentrate, respectively.

\section{Conclusion}

The presented data indicate that the introduction of modified soy concentrate and soy concentrate into the composition of the minced meat system is accompanied by a decrease in the values of the cutting work and shear stress indicators. As a result, the use of highly functional soy products leads to a significant improvement in properties that determine the structural and mechanical characteristics of combined minced products. The use of $25 \%$ modified soy concentrate and soy concentrate in cooked sausages improves texture, increases product yield, makes the product easy to cut.

Thus, in terms of the range of functional properties, all studied concentrates correspond to soy protein concentrates produced by traditional technology. A characteristic feature of the preparations is a slight dependence of protein solubility on temperature and sodium chloride content in solution. The research results indicate a similar behavior of suspensions of modified soy concentrates and soy concentrates from soybeans of local varieties in cooked sausages.

\section{References}

1. S. Isaev, I. Begmatov, G. Goziev, S. Khasanov, IOP Publishing 883(1), 012080 (2020)

2. L. V. Antipova, I. A. Glotova, Use of secondary collagen-containing raw materials of the meat industry, 384 (GIORD Press, Saint Petersburg, 2006)

3. V. N. Golubev, L. V. Chicheva-Filatova, T. V. Shlenskaya, Nutritional and biological active additives, 208 (Academia Press, Moscow, 2003)

4. A. B. Lisitsyn, N. N. Lipatov, L. S. Kudryashov, V. A. Aleksakhina, Production of meat products based on biotechnology, 369 (VNIIMP Press, Moscow, 2005)

5. A. B. Lisitsyn, Processing and use of by-products of the meat industry and environmental protection, 101 (VNIIMP Press, Moscow, 2000)

6. I. A. Rogov, Technology of meat and meat products, 356 (Kolos Press, Moscow, 2009)

7. A. Fathullaev, S. M. Turabjanov, International Magazine Austria, 63-69 (2018)

8. A. Fathullaev, S. M. Turabjanov, J. Chemistry and Chemical Technology 4, 74-76 (2008)

9. A. Fathullaev, Polish Journal of Science 1(24), 23-30 (2020)

10. A. Fathullaev, International Journal of Psychosocial Rehabilitation 24(8), 5858-5864 (2020)

11. A. Fathullaev, European Journal of Technical and Natural Sciences 3, 63-72 (2020) 